\title{
DOKUMENTATION
}

\section{BASEL CONVENTION ON THE CONTROL OF TRANSBOUNDARY MOVEMENTS OF HAZARDOUS WASTES AND THEIR DISPOSAL1}

Signed on 22 March, 1989

\section{PREAMBLE}

The Parties to this Convention,

Aware of the risk of damage to human health and the environment caused by hazardous wastes and the transboundary movement thereof,

Mindful of the growing threat to human health and the environment posed by the increased generation and complexity, and transboundary movement of hazardous wastes and other wastes,

Mindful also that the most effective way of protecting human health and the environment from the dangers posed by such wastes is the reduction of their generation to a minimum in terms of quantity and /or hazard potential,

Convinced that States should take necessary measures to ensure that the management of hazardous wastes and other wastes including their transboundary movement and disposal is consistent with with the protection of human health and the environment whatever the place of their disposal,

Noting that States should ensure that the generator should carry out duties with regard to the transport and disposal of hazardous wastes and other wastes in a manner that is consistent with the protection of the environment, whatever the place of disposal,

Fully recognizing that any State has the sovereign right to ban the entry or disposal of foreign hazardous wastes and other wastes in its territory,

1 The Final Act of the conference and the Annexes have been published with the Convention in 28 I L M 649 (1989). 
Recognizing also the increasing desire for the prohibition of transboundary movements of hazardous wastes and their disposal in other States, especially developing countries,

Convinced that hazardous wastes and other wastes should, as far as is compatible with environmentally sound and efficient management, be disposed of in the State where they were generated,

Aware also that transboundary movements of such wastes from the State of their generation to any other State should be permitted only when conducted under conditions which do not endanger human health and the environment, and under conditions in conformity with the provisions of this Convention,

Considering that enhanced control of transboundary movement of hazardous wastes and other wastes will act as an incentive for their environmentally sound management and for the reduction of the volume of such transboundary movement,

Convinced that States should take measures for the proper exchange of information on and control of the transboundary movement of hazardous wastes and other wastes from and to those States,

Noting that a number of international and regional agreements have addressed the issue of protection and preservation of the environment with regard to the transit of dangerous goods,

Taking into account the Declaration of the United Nations Conference on the Human Environment (Stockholm, 1972), the Cairo Guidelines and Principles for the Environmentally Sound Management of Hazardous Wastes adopted by the Goveming Council of the United Nations Environment Programme (UNEP) by decision 14/30 of 17 June 1987, the Recommendations of the United Nations Committee of Experts on the Transport of Dangerous Goods (formulated in 1957 and updated biannually), relevant recommendations, declarations, instruments and regulations adopted within the United Nations System and the work and studies done within other international and regional organizations,

Mindful of the spirit, principles, aims and functions of the World Charter for Nature adopted by the General Assembly of the United Nations at its thirty-seventh session (1982) as the rule of ethics in respect of the protection of the human environment and the conservation of natural ressources,

Affirming that States are responsible for the fulfilment of their international obligations concerning the protection of the human health and protection and preservation of the environment, and are liable in accordance with international law, 
Recognizing that in the case of a material breach of the provisions of this Convention or any protocol thereto the relevant intemational law of treaties shall apply,

Aware of the need to continue the development and implementation of environmentally sound low-waste technologies, recycling options, good house-keeping and management systems with a view to reducing to a minimum the generation of hazardous wastes and other wastes,

Aware also of the growing international concem about the need for stringent control of transboundary movement of hazardous wastes and other wastes, and of the need as far as possible to reduce such movement to a minimum,

Concemed about the problem of illegal transboundary traffic in hazardous wastes and other wastes,

Taking into account also the limited capabilities of the developing countries to manage hazardous wastes and other wastes,

Recognizing the need to promote the transfer of technology for the sound management of hazardous wastes and other wastes produced locally, particularly to the developing countries in accordance with the spirit of the Cairo Guidelines and decision 14/16 of the Governing Council of UNEP on Promotion of the transfer of environmental protection technology,

Recognizing also that hazardous wastes and other wastes should be transported in accordance with relevant international conventions and recommendations,

Convinced also that the transboundary movement of hazardous wastes and other wastes should be permitted only when the transport and the ultimate disposal of such wastes is environmentally sound, and

Determined to protect, by strict control, human health and the environment against the adverse effects which may result from the generation and management of hazardous wastes and other wastes,

HAVE AGREED AS FOLLOWS: 


\section{$\underline{\text { Article } 1}$}

\section{Scope of the Convention}

1. The following wastes that are subject to transboundary movement shall be "hazardous wastes" for the purposes of this Convention:

(a) Wastes that belong to any category contained in Annex I, unless they do not possess any of the characteristics contained in Annex III; and

(b) Wastes that are not covered under paragraph (a) but are defined as, or are considered to be, hazardous wastes by the domestic legislation of the Party of export, import or transit.

2. Wastes that belong to any category contained in Annex II that are subject to transboundary movement shall be "other wastes" for the purposes of this Convention.

3. Wastes which, as a result of being radioactive, are subject to other international control systems, including international instruments, applying specifically to radioactive materials, are excluded from the scope fo this Convention.

4. Wastes which derive from the normal operations of a ship, the discharge of which is covered by another international instrument, are excluded from the scope of this Convention.

\section{Article 2}

\section{Definitions}

For the purposes of this Convention:

1. "Wastes" are substances or objects which are disposed of or are intended to be disposed of or are required to be disposed of by the provisions of national law;

2. "Management" means the collection, transport and disposal of hazardous wastes or other wastes, including after-care of disposal sites;

3. "Transboundary movement" means any movement of hazardous wastes or other wastes from the area under the national jurisdiction of one State to or through an area under the 
national jurisdiction of another State or to or through an area not under the national jurisdiction of any State, provided at least two States are involved in the movement;

4. "Disposal" means any operation specified in Annex IV to this Convention;

5. "Approved site or facility" means a site or facility for the disposal of hazardous wastes or other wastes which is authorized or permitted to operate for this purpose by a relevant authority of the State where the site or facility is located;

6. "Competent authority" means one govemmental authority designated by a Party to be responsible, within such geographical areas as the Party may think fit, for receiving the notification of a transboundary movement of hazardous wastes or other wastes, and any information related to it, and for responding to such a notification, as provided in Article 6;

7. "Focal point" means the entity of a Party referred to in Article 5 responsible for receiving and submitting information as provided for in Articles 13 and 15;

8. "Environmentally sound management of hazardous wastes or other wastes" means taking all practicable steps to ensure that hazardous wastes or other wastes are managed in a manner which will protect human health and the environment against the adverse effects which may result from such wastes;

9. "Area under the national jurisdiction of a State" means any land, marine area or airspace within which a State exercises administrative and regulatory responsibility in accordance with international law in regard to the protection of human health or the environment;

10. "State of export" means a Party from which a transboundary movement of hazardous wastes or other wastes is planned to be initiated or is initiated;

11. "State of import" means a party to which a transboundary movement of hazardous wastes or other wastes is planned or takes place for the purpose of disposal therein or for the purpose of loading prior to disposal in an area not under the national jurisdiction of any State;

12. "State of transit" means any State, other than the State of export or import, through which a movement of hazardous wastes or other wastes is planned or takes place;

13. "States concerned" means Parties which are States of export or import, or transit States, whether or not Parties; 
14. "Person" means any natural or legal person;

15. "Exporter" means any person under jurisdiction of the State of export who arranges for hazardous wastes to be exported;

16. "Importer" means any person under the jurisdiction of the State of import who arranges for hazardous wastes or wastes to be imported;

17. "Carrier" means any person who carries out the transport of hazardous wastes or other wastes;

18. "Generator" means any person whose activity produces hazardous wastes or other wastes or, if that person is not known, the person who is in possession and/or control of those wastes;

19. "Disposer" means any person to whom hazardous wastes or other wastes are shipped and who carries out the disposal of such wastes;

20. "Political and/or economic integration organization" means an organization constituted by sovereign States to which its member States have transferred competence in respect of matters governed by this Convention and which has been duly authorized, in accordance with its internal procedures, to sign, accept, approve, formally conf irm or accede to it;

21. "Illegal traffic" means any transboundary movement of hazardous wastes or other wastes as specified in Article 9.

\section{Article 3}

\section{National Definitions of Hazardous Wastes}

1. Each Party shall, within six months of becoming a Party of this Convention, inform the Secretariat of the Convention of the wastes, other than those listed in Annexes I and II, considered or defined as hazardous under its national legislation and of any requirements concerning transboundary movement procedures applicable to such wastes.

2. Each Party shall subsequently inform the Secretariat of any significant changes to the information it has provided pursuant to paragraph 1.

3. The Secretariat shall forthwith inform all Parties of the information it has received pursuant to paragraphs 1 and 2 . 
4. Parties shall be responsible for making the information transmitted to them by the Secretariat under paragraph 3 available to their exporters.

\section{$\underline{\text { Article } 4}$}

\section{General Obligations}

1. (a) Parties exercising their right to prohibit the import of hazardous wastes or other wastes for disposal shall inform the other Parties of their decision pursuant Article 13.

(b) Parties shall prohibit or shall not permit the export of hazardous wastes and other wastes to the Parties which have prohibited the import of such wastes, when notified pursuant to subparagraph (a) above.

(c) Parties shall prohibit or shall not permit the export of hazardous wastes and other wastes if the State of import does not consent in writing to the specific import, in the case where that State of import has not prohibited the import of such wastes.

2. Each Party shall take the appropriate measures to:

(a) Ensure that the generation of hazardous wastes and other wastes within it is reduced to a minimum, taking into account social, technological and economic aspects;

(b) Ensure the availibility of adequate disposal facilities, for the environmentally sound management of hazardous wastes and other wastes, that shall be located, to the extent possible, within it, whatever the place of their disposal;

(c) Ensure that persons involved in the management of hazardous wastes and other wastes within it take such steps as are necessary to prevent pollution due to hazardous wastes and other wastes arising from such management and, if such pollution occurs, to minimize the consequences thereof for human health and the environment;

(d) Ensure that the transboundary movement of hazardous wastes and other wastes is reduced to the minimum consistent with the environmentally sound and efficient management of such wastes, and is conducted in a manner which will protect human health and the environment against the adverse effects which may result from such a movement;

(e) Not allow the export of hazardous wastes or other wastes to a State or group of States belonging to an economic and/or political integration organization that are Parties, particularly developing countries, which have prohibited by their legislation all imports, or 
if it has reason to believe that the wastes in question will not be managed in an environmentally sound manner, according to criteria to be decided on by the Parties at their first meeting.

(f) Require that information about a proposed transboundary movement of hazardous wastes and other wastes be provided to the States concerned, according to Annex V A, to state clearly the effects of the proposed movement on human health and the environment;

(g) Prevent the import of hazardous wastes and other wastes if it has reason to believe that the wastes in question will not be managed in an environmentally sound manner;

(h) Co-operate in activities with other Parties and interested organizations, directly and through the Secretariat, including the dissemination of information on the transboundary movement of hazardous wastes and other wastes, in order to improve the environmentally sound management of such wastes and to achieve the prevention of illegal traffic;

3. The Parties consider that illegal traffic in hazardous wastes or other wastes is criminal.

4. Each party shall take appropriate legal, administrative and other measures to implement and enforce the provisions of this Convention, including measures to prevent and punish conduct in contravention of the Convention.

5. A Party shall not permit hazardous wastes or other wastes to be exported to a non-Party or to be imported from a non-Party.

6. The Parties agree not to allow the export of hazardous wastes or other wastes for disposal within the area south of $60^{\circ}$ South latitude, whether or not such wastes are subject to transboundary movement.

\section{$\underline{\text { Article } 5}$}

\section{Designation of Competent Authorities and Focal Point}

To facilitate the implementation of this Convention, the Parties shall:

1. Designate or establish one or more competent authorities and one focal point. One competent authority shall be designated to receive the notification in case of State of transit. 
2. Inform the Secretariat, within three months of the date of the entry into force of this Convention for them, which agencies they have designated as their focal point and their competent authorities.

3. Inform the Secretariat, within one month of the date of decision, of any changes regarding the designation made by them under paragraph 2 above.

\section{Article 6}

\section{Transboundary Movement between Parties}

1. The State of export shall notify, or shall require the generator or exporter to notify, in writing, through the channel of the competent authority of the States concerned of any proposed transboundary movement of hazardous wastes or other wastes. Such notification shall contain the declarations and informations specified in Annex V A, written in a language acceptable to the State of import. Only one notification needs to be sent to each State concerned.

2. The State of import shall respond to the notifier in writing, consenting to the movement with or without conditions, denying permission for the movement, or requesting additional information. A copy of the final response of the State of import shall be sent to the competent authorities of the State concerned which are Parties.

3. The State of export shall not allow the generator or exporter to commence the transboundary movement until it has received written confirmation that:

(a) The notifier has received the written consent of the State of import; and

(b) The notifier has received from the State of import confirmation of the existence of a contract between the exporter and the disposer specifying environmentally sound management of the wastes in question.

4. Each State of transit which is a Party shall promptly acknowledge to the notifier receipt of the notification. It may subsequently respond to the notifier in writing, within 60 days, consenting to the movement with or without conditions, denying permission for the movement, or requesting additional information. The State of export shall not allow the transboundary movement to commence until it has received the written consent of the State of transit. However, if at any time a Party decides not to require prior written consent, either generally or under specific conditions, for transit transboundary movements of hazardous wastes or other wastes, or modifies its requirements in this respect, it shall 
forthwith inform the other Parties of its decision pursuant to Article 13. In this latter case, if no response is received by the State of export within 60 days of the receipt of a given notification by the State of transit, the State of export may allow the export to proceed through the State of transit.

5. In the case of a transboundary movement of wastes where the wastes are legally defined as or considered to be hazardous wastes only:

(a) By the State of export, the requirements of paragraph 9 of this Article that apply to the importer or disposer and the State of import shall apply mutatis mutandis to the exporter and State of export, respectively;

(b) By the State of import, or by the States of import and transit which are Parties, the requirements of paragraphs 1, 3,4 and 6 of this article that apply to the exporter and State of export shall apply mutatis mutandis to the importer or disposer and State of import, respectively; or

(c) By any State of transit which is a Party, the provisions of paragraph 4 shall apply to such State.

6. The State of export may, subject to the written consent of the States concerned, allow the generator or the exporter to use a general notification where hazardous wastes or other wastes having the same physical and chemical characteristics are shipped regularly to the same disposer via the same customs office of exit of the State of export via the same customs office of entry of the State of import, and, in the case of transit, via the same customs office of entry and exit of the State or States of transit.

7. The States concerned may make their written consent to the use of the general notification referred to in paragraph 6 subject to the supply of certain information, such as the exact quantities or periodical lists of hazardous wastes or other wastes to be shipped.

8. The general notification and written consent referred to in paragraphs 6 and 7 may cover multiple shipments of hazardous wastes or other wastes during a maximum period of 12 months.

9. The Parties shall require that each person who takes charge of a transboundary movement of hazardous wastes or other wastes sign the movement document either upon delivery or receipt of the wastes in question. They shall also require that the disposer inform both the exporter and the competent authority of the State of export of receipt by the disposer of the wastes in question and, in due course, of the completion of disposal as specified in the notification. If no such information is received within the State of export, 
the competent authority of the State of export or the exporter shall so notify the State of import.

10. The notification and response required by this Article shall be transmitted to the competent authority of the Parties concerned or to such governmental authority as may be appropriate in the case of non-Parties.

11. Any transboundary movement of hazardous wastes shall be covered by insurance, bond or other guarantee as may be required by the State of import or any State of transit which is a Party.

\section{Article 7}

Transboundary Movement from a Party through States which are not Parties

Paragraph 2 of Article 6 of the Convention shall apply mutatis mutandis to transboundary movement of hazardous wastes or other waste from a Party through a State or States which are not Parties.

\section{Article 8}

\section{Duty to Re-import}

When a transboundary movement of hazardous wastes or other wastes to which the consent of the States concerned has been given, subject to the provisions of this Convention, cannot be completed in accordance with the terms of the contract, the State of export shall ensure that the wastes in question are taken back into the State of export, by the exporter, if alternative arrangements cannot be made for their disposal in an environmentally sound manner, within 90 days from the time that the importing State informed the State of export and the Secretariat, or such other period of time as the States concerned agree. To this end, the State of export and any Party of transit shall not oppose, hinder or prevent the return of those wastes to the State of. export. 


\section{Article 9}

\section{$\underline{\text { Illegal Traffic }}$}

1. For the purpose of this Convention, any transboundary movement of hazardous or other wastes:

(a) without notification pursuant to the provisions of this Convention to all States concerned; or

(b) without the consent pursuant to the provisions of this Convention of a State concerned; or

(c) without consent obtained from States concerned through falsification, misrepresentation or fraud; or

(d) that does not conform in a material way with the documents; or

(e) that results in deliberate disposal (e.g. dumping) of hazardous wastes or other wastes in contravention of this Convention and of general principles of international law,

shall be deemed to be illegal traffic.

2. In case of a transboundary movement of hazardous wastes or other wastes deemed to be illegal traffic as the result of conduct on the part of the exporter or generator, the State of export shall ensure that the wastes in question are:

(a) taken back by the exporter or the generator or, if necessary, by itself into the State of export, or, if impracticable,

(b) are otherwise disposed of in accordance with the provisions of this Convention,

within 30 days from the time the State of export has been informed about the illegal traffic or such other period of time as States concerned may agree. To this end the Parties concerned shall not oppose, hinder or prevent the return of those wastes to the State of export.

3. In the case of a transboundary movement of hazardous wastes or other wastes deemed to be illegal traffic as the result of conduct on the part of the importer or disposer, the State of import shall ensure that the wastes in question are disposed of in an environmentally sound manner by the importer or disposer or, if necessary, by itself within 30 days from the 
time the illegal traffic has come to the attention of the State of import or such other period of time as the States concerned may agree. To this end, the Parties concerned shall cooperate, as necessary, in the disposal of the wastes in an environmentally sound manner.

4. In cases where the responsibility for the illegal traffic cannot be assigned either to the exporter or generator or to the importer or disposer, the Parties concerned or other Parties, as appropriate, shall ensure, through co-operation, that the wastes in question are disposed of a soon as possible in an environmentally sound manner either in the State of export or the State of import or elsewhere as appropriate.

5. Each party shall introduce appropriate national/domestic legislation to prevent and punish illegal traffic. The Parties shall co-operate with a view to achieving the objects of this Article.

\section{Article 10}

\section{International Co-operation}

1. The Parties shall co-operate with each other in order to improve and achieve environmentally sound management of hazardous wastes and other wastes.

2. To this end, the Parties shall:

(a) Upon request, make available information, whether on a bilateral or multilateral basis, with a view to promoting the environmentally sound management of hazardous wastes and other wastes, including harmonization of technical standards and practices for the adequate management of hazardous wastes and other wastes;

(b) Co-operate in monitoring the effects of the management of hazardous wastes on human health and the environment;

(c) Co-operate, subject to their national laws, regulations and policies, in the development and implementation of new environmentally sound low-waste technologies and the improvement of existing technologies with a view to elimination, as far as practicable, the generation of hazardous wastes and other wastes and achieving more effective and efficient methods of ensuring their management in an environmentally sound manner, including the study of the economic, social and environmental effects of the adoption of such new or improved technologies; 
(d) Co-operate actively, subject to their national laws, regulations and policies, in the transfer of technology and management systems related to the environmentally sound management of hazardous wastes and other wastes. They shall also co-operate in developing the technical capacity among Parties, especially those which may need and request technical assistance in this field;

(e) Co-operate in developing appropriate technical guidelines and/or codes of practice.

3. The Parties shall employ appropriate means to co-operate in order to assist developing countries in the implementation of subparagraphs a, b and c of paragraph 2 of Article 4.

4. Taking into account the needs of developing countries, co-operation between Parties and the competent international organizations is encouraged to promote, inter alia, public awareness, the development of sound management of hazardous wastes and other wastes and the adoption of new low-waste technologies.

\section{Article 11}

\section{Bilateral, Multilateral and Regional Agreements}

1. Notwithstanding the provisions of Article 4 paragraph 5, Parties may enter into bilateral, multilateral, or regional agreements or arrangements regarding transboundary movement of hazardous wastes or other wastes with Parties or non-Parties provided that such agreements or arrangements do derogate from the environmentally sound management of hazardous wastes and other wastes as required by this Convention. These agreements or arrangements shall stipulate provisions which are not less environmentally sound than those provided for by this Convention in particular taking into account the interests of developing countries.

2. Parties shall notify the Secretariat of any bilateral, multilateral or regional agreements or arrangements referred to in paragraph 1 and those which they have entered into prior to the entry into force of this Convention for them, for the purpose of controlling transboundary movements of hazardous wastes and other wastes which take place entirely among the Parties to such agreements. The provisions of this Convention shall not affect transboundary movements which take place pursuant to such agreements provided that such agreements are compatible with the environmentally sound management of hazardous wastes and other wastes as required by this Convention. 


\section{$\underline{\text { Article } 12}$}

\section{Consultations on Liability}

The Parties shall co-operate with a view to adopting, as soon as practicable, a protocol setting out appropriate rules and procedures in the field of liability and compensation for damage resulting from the transboundary movement and disposal of hazardous wastes and other wastes.

\section{$\underline{\text { Article } 13}$}

\section{Transmission of Information}

1. The Parties shall, whenever it comes to their knowledge, ensure that, in the case of an accident ocurring during the transboundary movement of hazardous wastes or other wastes or their disposal, which are likely to present risks to human health and the environment in other States, those states are immediately informed.

2. The Parties shall inform each other, through the Secretariat, of:

(a) Changes regarding the designation of competent authorities and/or focal points, pursuant to Article 5;

(b) Changes in their national definitions of hazardous wastes, pursuant to Article 3;

and, as soon as possible,

(c) Decisions made by them not to consent totally or partially to the import of hazardous wastes or other wastes for disposal within the area under their national jurisdiction;

(d) Decisions taken by them to limit or ban the export of hazardous wastes or other wastes;

(e) Any other information required pursuant to paragraph 4 of this Article.

3. The Parties, consistent with national laws and regulations, shall transmit, through the Secretariat, to the Conference of the Parties established under Article 15, before the end of each calendar year, a report on the previous calendar year, containing the following information: 
(a) Competent authorities and focal points that have been designated by them pursuant to Article 5;

(b) Information regarding transboundary movements of hazardous wastes or other wastes in which they have been involved, including:

(i) The amount of hazardous wastes and other wastes exported, their category, characteristics, destination, any transit country and disposal method as stated on the response to notification;

(ii) The amount of hazardous wastes and other wastes imported, their category, characteristics, origin, and disposal methods;

(iii) Disposals which did not proceed as intended;

(iv) Efforts to achieve a reduction of the amount of hazardous wastes or other wastes subject to transboundary movement;

(c) Information on the measures adopted by them in implementation of this Convention;

(d) Information on available qualified statistics which have been compiled by them on the effects on human health and the environment of the generation, transportation and disposal of hazardous wastes or other wastes;

(e) Information concerning bilateral, multilateral and regional agreements and arrangements entered into pursuant to Article 11 of this Convention;

(f) Information on accidents occuring during the transboundary movement and disposal of hazardous wastes and other wastes and on the measures undertaken to deal with them;

(g) Information on disposal options operated within the area of their national jurisdiction;

(h) Information on measures undertaken for development of technologies for the reduction and/or elimination of production of hazardous wastes or other wastes; and

(i) Such other matters as the Conference of the Parties shall deem relevant. 
4. The Parties, consistent with national laws and regulations, shall ensure that copies of each notification conceming any given transboundary movement of hazardous wastes or other wastes, and the response to it, are sent to the Secretariat when a Party considers that its environment may be affected by that transboundary movement has requested that this should be done.

\section{$\underline{\text { Article } 14}$}

\section{Financial Aspects}

1. The Parties agree that, according to the specific needs of different regions and subregions, regional or sub-regional centres for training and technology transfers regarding the management of hazardous wastes and other wastes and the minimization of their generation should be established. The Parties shall decide on the establishment of appropriate funding mechanisms of a voluntary nature.

2. The Parties shall consider the establishment of a revolving fund to assist on an interim basis in case of emergency situations to minimize damage from accidents arising from transboundary movements of hazardous wastes and other wastes of during the disposal of those wastes.

\section{$\underline{\text { Article } 15}$}

\section{Conference of the Parties}

1. A Conference of the Parties is hereby established. The first meeting of the Conference of the Parties shall be convened by the Executive Director of UNEP not later than one year after the entry into force of this Convention. Thereafter, ordinary meetings of the Conference of the Parties shall be held at regular intervals to be determined by the Conference at its first meeting.

2. Extraordinary meetings of the Conference of the Parties shall be held at such other times as may be deemed necessary by the Conference, or at the written request of any Party, provided that, within six months of the request being communicated to them by the Secretariat, it is supported by at least one third of the Parties.

3. The Conference of the Parties shall by consensus agree upon and adopt rules of procedure for itself and for any subsidiary body it may establish, as well as financial rules to determine in particular the financial participation of the Parties under this Convention. 
4. The Parties at their first meeting shall consider any additional measures needed to assist them in fulfilling their responsibilities with respect to the protection and the preservation of the marine environment in the context of this Convention.

5. The Conference of the Parties shall keep under continuous review and evaluation the effective implementation of this Convention, and, in addition, shall:

(a) Promote the harmonization of appropriate policies, strategies and measures for minimizing harm to human health and the environment by hazardous wastes and other wastes;

(b) Consider and adopt, as required, amendments to this Convention and its annexes, taking into consideration, inter alia, available scientific, technical, economic and environmental information;

(c) Consider and undertake any additional action that may be required for the achievement of the purposes of this Convention in the light of experience gained in its operation and in the operation of the agreements and arrangements envisaged in Article 11;

(d) Consider and adopt protocols as required; and

(e) Establish such subsidiary bodies as are deemed necessary for the implementation of this Convention.

6. The United Nations, its specialized agencies, as well as any State not party to this Convention, may be represented as observers at meetings of the Conference of the Parties. Any other body or agency, whether national or intemational, govemmental or non-govemmental, qualified in fields of related to hazardous wastes or other wastes which has informed the Secretariat of its wish to be represented as an observer at a meeting of the Conference of the Parties, may be admitted unless at least one third of the Parties present object. The admission and participation of observers shall be subject to the rules of procedure adopted by the Conference of the Parties.

7. The Conference of the Parties shall undertake three years after the entry into force of this Convention, and at least every six years thereafter, an evaluation of its effectiveness and, if deemed necessary, to consider the adoption of a complete or partial ban of transboundary movements of hazardous wastes and other wastes in light of the latest scientific, environmental, technical and economic information. 


\section{Article 16}

\section{$\underline{\text { Secretariat }}$}

1. The functions of the Secretariat shall be:

(a) To arrange for and service meetings provided for in Article 15 and 17;

(b) To prepare and transmit reports based upon information received in accordance with Articles 3, 4, 6, 11 and 13 as well as upon information derived from meetings of subsidiary bodies established under Article 15 as well as upon, as appropriate, information provided by relevant intergovernmental and non-governmental entities;

(c) To prepare reports on its activities carried out in implementation of its functions under this Convention and present them to the Conference of the Parties;

(d) To ensure the necessary coordination with relevant international bodies, and in particular to enter into such administrative and contractual arrangements as may be required for the effective discharge of its functions;

(e) To communicate with focal points and competent authorities established by the Parties in accordance with Article 5 of this Convention;

(f) To compile information concerning authorized national sites and facilities of Parties available for the disposal of their hazardous wastes and other wastes and to circulate this information among Parties;

(g) To receive and convey information from and to Parties on:

- sources of technical assistance and training;

- available technical and scientific know-how;

- sources of advice and expertise; and

- availability of resources

with a view to assisting them, upon request, in such areas as:

- the handling of the notification system of this Convention;

- the management of hazardous wastes and other wastes;

- environmentally sound technologies relating to hazardous wastes and other wastes, such as low- and non-waste technology;

- the assessment of disposal capabilities and sites; 
- the monitoring of hazardous wastes and other wastes; and

- emergency responses;

(h) To provide Parties, upon request, with information on consultants or consulting firms having the necessary technical competence in the field, which can assist them to examine a notification for a transboundary movement, the concurrence of a shipment of hazardous wastes or other wastes with the relevant notification, and/or the fact that the proposed disposal facilities for hazardous wastes or other wastes are environmentally sound, when they have reason to believe that the wastes in question will not be managed in an environmentally sound manner. Any such examination would not be at the expense of the Secretariat;

(i) To assist Parties upon request in their identification of cases of illegal traffic and to circulate immediately to the Parties concerned any information it has received regarding illegal traffic;

(j) To co-operate with Parties and with relevant and competent international organizations and agencies in the provisions of experts and equipment for the purpose of rapid assistance to States in the event of an emergency situation; and

(k) To perform such other functions relevant to the purpose of this Convention as may be determined by the Conference of the Parties.

2. The secretariat functions will be carried out on an interim basis by UNEP until the completion of the first meeting of the Conference of the Parties held pursuant to Article 15.

3. At its first meeting, the Conference of the Parties shall designate the Secretariat from among those existing competent intergovemmental organizations which have signified their willingness to carry out the secretariat functions under this Convention. At this meeting, the Conference of the Parties shall also evaluate the implementation by the interim Secretariat of the functions assigned to it, in particular under paragraph 1 above, and decide upon the structures appropriate for those functions.

\section{$\underline{\text { Article } 17}$}

\section{Amendment of the Convention}

1. Any Party may propose amendments to this Convention and any Party to a protocol may propose amendments to that shall take due account, inter alia, of relevant scientific and technical considerations. 
2. Amendments to this Convention shall be adopted at a meeting of the Conference of the Parties. Amendments to any protocol shall be adopted at a meeting of the Parties to the protocol in question. The text of any proposed amendment to this Convention or to any protocol, except as may otherwise be provided in such protocol, shall be communicated to the Parties by the Secretariat at least six months before the meeting at which it is proposed for adoption. The Secretariat shall also communicate proposed amendments to the Signatories to this Convention for information.

3. The Parties shall make every effort to reach agreement on any proposed amendment to this Convention by consensus. If all efforts at consensus have been exhausted, and no agreement reached, the amendment shall as a last resort be adopted by a three-fourths majority vote of the Parties present and voting at the meeting, and shall be submitted by the Depositary to all Parties for ratification, approval, formal confirmation or acceptance.

4. The procedure mentioned in paragraph 3 above shall apply to amendments to any protocol, except that a two-thirds majority of the Parties to that protocol present and voting at the meeting shall suffice for their adoption.

5. Instruments of ratification, approval, formal confirmation or acceptance of amendments shall be deposited with the Depositary. Amendments adopted in accordance with paragraphs 3 or 4 above shall enter into force between Parties having accepted them on the ninetieth day after the receipt by the Depositary of their instrument of ratification, approval, formal confirmation or acceptance by at least three-fourths of the Parties who accepted the amendments to the protocol concerned, except as may otherwise be provided in such protocol. The amendments shall enter into force for any other Party on the ninetieth day after that Party deposits its instrument of ratification, approval, formal confirmation or acceptance of the amendments.

6. For the purpose of this Article, "Parties present and voting" means Parties present and casting an affirmative or negative vote.

\section{$\underline{\text { Article } 18}$}

\section{Adoption and Amendment of Annexes}

1. The annexes to this Convention or to any protocoll shall form an integral part of this Convention or of such protocol, as the case may be and, unless expressly provided otherwise, a reference to this Convention or its protocols constitutes at the same time a reference to any annexes thereto. Such annexes shall be restricted to scientific, technical and administrative matters. 
2. Except as may be otherwise provided in any protocol with respect to its annexes, the following procedure shall apply to the proposal, adoption and entry into force of additional annexes to this Convention or of annexes to a protocol:

(a) Annexes to this Convention and its protocols shall be proposed and adopted according to the procedure laid down in Article 17, paragraphs 2, 3 and 4;

(b) Any Party that is unable to accept any additional annex to this Convention or an annex to any protocol to which it is party shall so notify the Depositary, in writing, within six months from the date of the communication of the adoption by the Depositary. The Depositary shall without delay notify all Parties of any such notification received. A Party may at any time substitute an acceptance for a previous declaration of objection and the annexes shall thereupon enter into force for that Party;

(c) On the expiry of six months from the date of the circulation of the communication by the Depositary, the annex shall become effective for all Parties to this Convention or to any protocol concerned, which have not submitted a notification in accordance with the provision of subparagraph (b) above.

3. The proposal, adoption and entry into force of amendments to annexes to this Convention or to any protocol shall be subject to the same procedure as for the proposal, adoption and entry into force of annexes to the Convention or annexes to protocol. Annexes and amendments thereto shall take due account, inter alia, of relevant scientific and technical considerations.

4. If an additional annex or an amendment to an annex involves an amendment to this Convention or to any protocol, the additional annex or amended annex shall not enter into force until such time as the amendment to this Convention or to the protocol enters into force.

\section{Article 19}

\section{$\underline{\text { Verification }}$}

Any Party which has reason to believe that another Party is acting or has acted in breach of its obligations under this Convention may inform the Secretariat thereof, and in such an event, shall simultaneously and immediately inform, directly or through the Secretariat, the Party against whom the allegations are made. All relevant information should be submitted by the Secretariat to the Parties. 


\section{Article 20}

\section{Settlement of Disputes}

1. In case of a dispute between Parties as to the interpretation or application of, or compliance with, this Convention or any protocol thereto, they shall seek a settlement or the dispute through negotiation or any other peaceful means of their own choice.

2. If the Parties concerned cannot settle their dispute through the means mentioned in the preceding paragraph, the dispute, if the parties to the dispute agree, shall be submitted to the International Court of Justice or to arbitration under the conditions set out in Annex VI on Arbitration. However, failure to reach common agreement on submission of the dispute to the International Court of Justice or to arbitration shall not absolve the Parties from the responsibility of continuing to seek to resolve it by the means referred to in paragraph 1 .

3. When ratifying, accepting, approving, formally confirming or acceding to this Convention, or at any time thereafter, a State or political and/or economic integration organization may declare that it recognizes as compulsory ipso facto and without special agreement, in relation to any Party accepting the same obligation:

(a) submission of the dispute to the International Court of Justice; and/or

(b) arbitration in accordance with the procedures set out in Annex VI.

Such declaration shall be notified in writing to the Secretariat which shall communicate it to the Parties.

\section{Article 21}

\section{$\underline{\text { Signature }}$}

This Convention shall be open for signature by States, by Namibia, represented by the United Nations Council for Namibia, and by political and/or economic integration organizations, in Basel on 22 March 1989, at the Federal Department of Foreign Affairs of Switzerland in Berne from 23 March 1989 to 30 June 1989, and at United Nations Headquarters in New York from 1 July 1989 to 22 March 1990. 


\section{$\underline{\text { Article } 22}$ \\ Ratification, Acceptance, Formal Confirmation or Approval}

1. This Convention shall be the subject to ratification, acceptance or approval by States and by Namibia, represented by the United Nations Council for Namibia, and to formal confirmation or approval by political and/or economic integration organizations. Instruments of ratification, acceptance, formal confirmation, or approval shall be deposited with the Depositary.

2. Any organization referred to in paragraph 1 above which becomes a Party to this Convention without any of its member States being a Party shall be bound by all the obligations under the Convention. In the case of such organizations, one or more of whose member States is a Party to the Convention, the organization and its member States shall decide on their respective responsibilities for the performance of their obligations under the Convention. In such cases, the organization and the member States shall not be entitled to exercise right under the Convention concurrently.

3. In their instruments of formal confirmation or approval, the organizations referred to in paragraph 1 above shall declare the extent of their competence with respect to the matters governed by the Convention. These organizations shall also inform the Depositary, who will inform the Parties of any substantial modification in the extent of their competence.

\section{$\underline{\text { Article } 23}$}

\section{$\underline{\text { Accession }}$}

1. This Convention shall be open for accession by States, by Namibia, and by political and/or economic integration organizations from the day after the date on which the Convention is closed for signature. The instruments of accession shall be deposited with the Depositary.

2. In their instruments of accession, the organizations referred to in paragraph 1 above shall declare the extent of their competence with respect to the matters governed by the Convention. These organizations shall also inform the Depositary of any substantial modification in the extent of their competence.

3. The provisions of Article 22 paragraph 2, shall apply to political and/or economic integration organizations which accede to this Convention. 


\section{Article 24}

\section{Right to Vote}

1. Except as provided for in paragraph 2 below, each Contracting Party to this Convention shall have one vote.

2. Political and/or economic integration organizations, in matters within their competence, in accordance with Article 22, paragraph 3, and Article 23, paragraph 2, shall exercise their right to vote with a number of votes equal to the number of their member States which are Parties to the Convention or the relevant protocol. Such organizations shall not exercise their right to vote if their member States exercise theirs, and vice versa.

\section{Article 25}

\section{Entry into Force}

1. This Convention shall enter into force on the ninetieth day after the date of deposit of the twentieth instrument of ratification, acceptance, formal confirmation, approval or accession.

2. For each State or political and/or economic integration organization which ratifies, accepts, approves or formally confirms this Convention or accedes thereto after the date of the deposit of the twentieth instrument of ratification, acceptance, approval, formal confirmation or accession, it shall enter into force on the ninetieth day after the day of deposit by such State or political and/or economic integration organization of its instrument of ratification, acceptance, approval, formal confirmation or accession.

3. For the purposes of paragraphs 1 and 2 above, any instrument deposited by a political and/or economic integration organization shall not be counted as additional to those deposited by member States of such organization.

\section{Article 26}

\section{Reservations and Declarations}

1. No reservation or exception may be made to this Convention. 
2. Paragraph 1 of this Article does not preclude a State or political and/or economic integration organizations, when signing, ratifying, accepting, approving, formally confirming or acceding to this Convention, from making declarations or statements, however phrased or named, with a view, inter alia, to the harmonization of its laws and regulations with the provisions of this Convention, provided that such declarations or statements do not purport to exclude or to modify the legal effects of the provisions of the Convention in their application to that State.

\section{Article 27}

\section{Withdrawal}

1. At any time after three years from the date on which this Convention has entered into force for a Party, that Party may withdraw from the Convention by giving written notification to the Depositary.

2. Withdrawal shall be effective one year from receipt of notification by the Depositary, or on such later date as may be specified in the notification.

\section{Article 28}

Depository

The Secretary-General of the United Nations shall be the Depository of this Convention and of any protocol thereto.

\section{Article 29}

\section{Authentic texts}

The original Arabic, Chinese, English, French, Russian and Spanish texts of this Convention are equally authentic.

IN WITNESS WHEREOF the undersigned, being duly authorized to that effect, have signed this Convention.

Done at

on the day of 1989 